\title{
Students' Creativity in Producing Biology Learning Media
}

\author{
Fajar Adinugraha
}

\author{
Biology Education Study Program, Indonesian Christian University \\ Corresponding Email: fadinugraha@yahoo.co.id, fajar.adinugraha@uki.ac.id
}

\begin{abstract}
As prospective teachers of Biology, students have to acquire appropriate competencies of being good teachers. The competencies must be supported by their creativity, which can be developed by doing some projects in their learning process through producing Biology learning media. The students in this article are pre-service teachers of Biology Education who are studying in the university. This article presents some descriptions of Biology learning media, which were created by the students in the form of spinning fauna in Indonesia, biosumpit cells, plantae quick responses, digestive system scrapbook, biology ladder snakes, virus question boards, female reproductive system, bio minilab, and human skin display. Through experimental study by one-shot case study, this article describes the level of students' creativity in creating the media as their final scores for Biology learning media project, which is in a good category with an average of $88.44 ; 17 \%$ (very good category) and $83 \%$ (good category). The students' creativity in producing Biology learning media is also in a high category with an average of 2.66; $28 \%$ (fair categories) and $72 \%$ (high categories). Therefore, the students' creativity which was supported by students and teachers in this study obtains the excellent final projects for Biology learning media.
\end{abstract}

Keywords: Creativity, Biology, Learning Media, Prospective Teachers, Learning Projects

\section{INTRODUCTION}

These competencies can affect the improving performance in teaching although social competencies have no significant effect (Fathorrahman, 2017:6). Nevertheless, social competencies are a factor of the success of the job. The competencies of teachers are needed to be improved such as a selection system about the attitude to prospective teachers, the quality of teachers, and about the development of characters (Susilowati et al., 2013: 91). The quality of teachers can be improved by developing the competencies that is needed by teachers (Bourgonje et al., 2011: 19). The learning media becomes inseparable things in Biology learning. It is an important thing in learning because it is an instrument to teach, to motivate students and teachers, to affect the learning climate, to affect the learning conditions, and to make the conducive learning situations (Mukti \& Nurcahyo, 2017: 138). Project Based Learning model was chosen in this subject because this model can improve the students' creativity. The creativity can realize the students to innovate in their school and the job. The creativity will make students to be happy and enthusiastic in learning. The positive response was given by students toward Project Based Learning model (Adinugraha, 2018:1-9). Furthermore, the project based learning models can improve the student learning outcomes and creativity (Surya et al., 2018: 41-54). It is also allowing students to improve academic achievement and develop students' positive attitudes (Weeksa et al., 2016: 25-31).

This article shows the description of Biology learning media that was created by the students. It is also to know the score of the Biology learning media projects. Furthermore, this article describes the level of students' creativity.

\section{METHOD}

The research method is an experimental research with one shot case study. It was carried out in 6th semester 2018/2019. The number of students was 18 students. The experiments using the project-based learning model were carried out in September to December 2018.

There are three data that was collected in this article. They are 1) description of Biology learning media, 2) students' score of the projects of Biology learning media, and 3) Students' creativity. First, the description of Biology learning media is to describe the characteristic of media such as Dimension on, color, and utility. Second, the score of Biology media learning project was collected from the final score include the form of the learning media, the process of production, 
and presentation. Third, student creativity data was collected by the questionnaires that consist of 42 questions. The question is based on four aspects of student creativity, namely 1) fluency, 2) flexibility, 3) original, and 4) elaboration.

\section{RESULTS}

This article contains 3 (three) topics: 1) the description of learning media project, 2) the description of the score of learning media project, and 3 ) the description of the level of students' creativity.

\section{The description of the learning media project}

Project work is carried out for \pm 3 months. Within these 3 months, students and their groups consulted with lecturers. In this case, the supporting lecturer is the author of this article. In fact, the frequency of consultation of each group is different. Some group even did not consult their project.

Table 1. Learning media projects in the Learning Media 2018/2019 course

\begin{tabular}{|c|c|c|c|c|}
\hline No & $\begin{array}{c}\text { Name of learning } \\
\text { media }\end{array}$ & Figure & $\begin{array}{c}\text { Basic competence (KI } 3 \\
\text { Cognitive) }\end{array}$ & Grade \\
\hline 1 & $\begin{array}{l}\text { Spinning fauna in } \\
\text { Indonesia Dimension: } \\
\text { Length }: 45 \mathrm{~cm} \\
\text { Width }: 33 \mathrm{~cm} \\
\text { Height }: 80 \mathrm{~cm}\end{array}$ & Spinning fauna di Indonesia & $\begin{array}{l}\text { 3.2. Analyze various levels of } \\
\text { biodiversity in Indonesia and their } \\
\text { threats and preservation and } \\
\text { threats and preservation (Chapter: } \\
\text { Biodiversity - Keanekaragaman } \\
\text { Hayati) }\end{array}$ & $\begin{array}{l}10 \\
\text { Semester } 1\end{array}$ \\
\hline 2 & $\begin{array}{l}\text { Biosumpit Cells } \\
\text { Dimension: } \\
\text { Length }: 60 \mathrm{~cm} \\
\text { Width }: 33 \mathrm{~cm} \\
\text { Height }: 116 \mathrm{~cm}\end{array}$ & Biosumpit Cells & $\begin{array}{l}\text { 3.1 Explain the chemical } \\
\text { components of the cell, its } \\
\text { structure, functions, and processes } \\
\text { that take place in a cell as the } \\
\text { smallest unit of life } \\
\text { (Chapter: Cell- Sel) }\end{array}$ & $\begin{array}{l}11 \\
\text { Semester } 3\end{array}$ \\
\hline 3 & $\begin{array}{l}\text { Plantae Quick } \\
\text { Responses } \\
\text { Dimension: } \\
\text { Length : } 32 \mathrm{~cm} \\
\text { Width : : } 20 \mathrm{~cm} \\
\text { Height }: 41 \mathrm{~cm}\end{array}$ & $\begin{array}{c}\text { Figure 3. Plantae Quick } \\
\text { Responses }\end{array}$ & $\begin{array}{l}3.8 \text { Classify the plants into divisio } \\
\text { based on general characteristics, } \\
\text { and linking their roles in our life } \\
\text { (Chapter: Kingdom Plantae) }\end{array}$ & $\begin{array}{l}10 \\
\text { Semester } 2\end{array}$ \\
\hline
\end{tabular}




\begin{tabular}{|c|c|c|c|c|}
\hline No & $\begin{array}{c}\text { Name of learning } \\
\text { media }\end{array}$ & Figure & $\begin{array}{c}\text { Basic competence (KI } 3 \\
\text { Cognitive) }\end{array}$ & Grade \\
\hline 5 & $\begin{array}{l}\text { Biology } \quad \text { Ladder } \\
\text { Snakes } \\
\text { Dimension: } \\
\text { Length : } 100 \mathrm{~cm} \\
\text { Width }: 2 \mathrm{~cm} \\
\text { Height }: 52 \mathrm{~cm}\end{array}$ & $\begin{array}{c}\text { Ular tangga Biologi } \\
\text { (Biology snakes and ladders) }\end{array}$ & $\begin{array}{l}\text { 3.1 Explain the influence of } \\
\text { internal factors and external } \\
\text { factors on the growth and } \\
\text { development of living things } \\
\text { (Chapter: Growth and } \\
\text { Development in organisms- } \\
\text { Pertumbuhan dan Perkembangan) }\end{array}$ & $\begin{array}{l}12 \\
\text { Semester } 5\end{array}$ \\
\hline 6 & $\begin{array}{l}\text { Virus Question } \\
\text { Boards } \\
\text { Dimension: } \\
\text { Length }: 80 \mathrm{~cm} \\
\text { Width }: 2 \mathrm{~cm} \\
\text { Height }: 58 \mathrm{~cm}\end{array}$ & 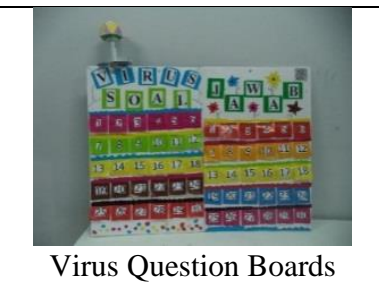 & $\begin{array}{l}\text { 3.4 Analyze the structure, } \\
\text { replication and role of viruses in } \\
\text { our life (Chapter: Viruses- Virus) }\end{array}$ & $\begin{array}{l}10 \\
\text { Semester } 1\end{array}$ \\
\hline 7 & $\begin{array}{l}\text { Female reproductive } \\
\text { system Dimension: } \\
\text { Length }: 55 \mathrm{~cm} \\
\text { Width }: 5 \mathrm{~cm} \\
\text { Height }: 40 \mathrm{~cm}\end{array}$ & Female reproductive system & $\begin{array}{l}\text { 3.12 Analyze the relationship } \\
\text { between the structure of tissues } \\
\text { that make up reproductive organs } \\
\text { and their functions in the human } \\
\text { reproductive system (Chapter: } \\
\text { Reproductive System- Sistem } \\
\text { Reproduksi) }\end{array}$ & $\begin{array}{l}11 \\
\text { Semester } 4\end{array}$ \\
\hline 8 & $\begin{array}{l}\text { Minilab bio } \\
\text { Dimension: } \\
\text { Length }: 50 \mathrm{~cm} \\
\text { Width }: 35 \mathrm{~cm} \\
\text { Height }: 16 \mathrm{~cm}\end{array}$ & Minilab bio & $\begin{array}{l}\text { 3.1 Explain the scope of biology } \\
\text { (problems at various biological } \\
\text { objects and levels of life } \\
\text { organization), through the } \\
\text { application of scientific methods } \\
\text { and principles of work safety. } \\
\text { (Chapter: Biology as a science- } \\
\text { Biologi sebagai Ilmu } \\
\text { Pengetahuan) }\end{array}$ & $\begin{array}{l}10 \\
\text { Semester } 1\end{array}$ \\
\hline 9 & $\begin{array}{l}\text { Human skin display } \\
\text { Dimension: } \\
\text { Length }: 45 \mathrm{~cm} \\
\text { Width }: 26 \mathrm{~cm} \\
\text { Height }: 33 \mathrm{~cm}\end{array}$ & Human skin display & $\begin{array}{l}\text { 3.9 Analyze the relationship } \\
\text { between the structure of tissues } \\
\text { making up organs in the excretion } \\
\text { system in relation to bioprocesses } \\
\text { and impaired functions that can } \\
\text { occur in the human excretion } \\
\text { system (Chapter: Excretion } \\
\text { System- Sistem Ekskresi) }\end{array}$ & $\begin{array}{l}11 \\
\text { Semester } 4\end{array}$ \\
\hline
\end{tabular}

This learning media is in the form of model from skin organs. These props are made from used cardboard coated with cardboard and trinkets to form the anatomy of the skin. The creativity and innovation will form the students' entrepreneurial skills. Entrepreneurial skills are entrepreneurial skills possessed by someone including creativity and academic knowledge
(Adinugraha, 2017: 219-233). Entrepreneurial skill data is then taken in this article from the value of learning media projects. 


\section{The description of the score of learning media projects}

The score of a learning media project is not just the score of its products but it is a combination of the process of production, product results, and learning media presentations. This is to show the creativity and academic knowledge about the learning media that created by students. Based on the analysis results of 18 students, it can be showed the score of learning media projects in [table 2] as follows.

Table 2. Data Description of the Score of Learning Media Projects

\begin{tabular}{|l|c|c|c|c|c|}
\hline & Respondent & Min score & Max score & Average of score & Stand. Of Deviation \\
\hline Project score & 18 & 87 & 92 & 88.44 & 1.464 \\
\hline
\end{tabular}

Based on [table 2], the average score of the learning media project is in the high category of 88.44 with a maximum value of 92 and a minimum value of 87. The data is clarified in [Figure 10] through a pie chart. The evaluation includes aspects of explaining the work, utility, innovation, creative power, and novelty.

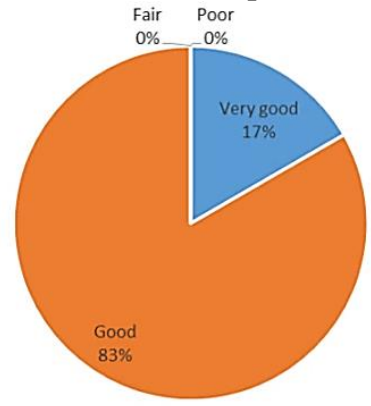

Figure 1 . The categories of learning media project score

Based on figure 1, it can be showed that all students get the score of project in the high category that 15 students $(83 \%)$ in the high category and 3 students $(17 \%)$ in the very high category. The students who get very high category (91-92) are students who make project namely spinning fauna in Indonesia. This learning media has a higher level of the novelty and the innovation than other learning media. Furthermore, students who make other learning media have score in the high category (87-89).

According to Mahnun (2012: 33), in choosing the learning media, the teacher must consider, such as: learning strategies, the ability to design and use media, cost considerations, facilities and infrastructure considerations, and efficiency and effectiveness considerations. Therefore, in this 21 st century learning, the teachers are required to be a creative and innovative person in learning. Teachers who are not creative and innovative, it make learning monotonous and nerveless. In line with this, Kupers et al. (2019: 93-124), said that the importance of creativity in the world of education is recognized as essential.

According to Adinugraha (2019: 4), the Local Wisdom and Cultural Approach (KALBU) has other advantages: 1) understanding the forms of local wisdom and culture around its environment, 2) adopting local wisdom and cultural values, 3) some local wisdom and culture can be linked in learning Biology. According to Fitria et al. (2017: 14-28), learning media in the form of Figure media can also be an alternative learning approach with local potential (local wisdom and culture).

\section{The description of the level of students' creativity}

The score (data) of student creativity is taken by a questionnaire that contain of 42 questions for 18 students. This score (data) is taken to show the level of the students' creativity from 4 (four) aspects of student creativity, such as 1) fluency, 2) flexibility, 3) original, and 4) elaborations. The data are analyzed and tabulated as [table 3] as follows.

Table 3. Data description of the score of students' creativity

\begin{tabular}{|l|c|c|c|c|c|}
\hline & Respondent & Min score & Max score & Average of score & Stand. Of Deviation \\
\hline Creativity score & 18 & 2.30 & 3.10 & 2.66 & 0.247 \\
\hline
\end{tabular}

Based on [table 2], the average of students' creativity scores is in the high category (2.66) with the maximum score is 3.10 and the minimum score is 2.30 . However, the score almost come near to the category range enough in scoring of 2.49. Data are clarified in [Figure 10] through a pie chart. 


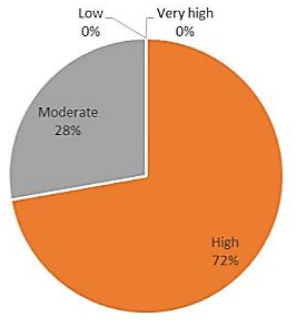

Figure 2 . The categories of the students' creativity score

Based on figure 2, it shows that all the students get a score of student's creativity in the high category that 13 students $(72 \%)$ in the high category and 5 students $(5 \%)$ in the fair category. Besides that, we also take the respondent's average per aspect is 1) fluency, 2) flexibility, 3) original, and 4) elaborations. The score on the mean of respondents by aspect is presented in figure 3 . The respondents have the highest creativity scores to the lowest in a row, namely fluency, flexibility, elaboration, and originality.

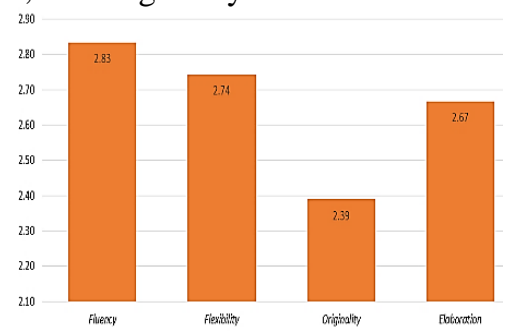

Figure 3. Score of students' creativity on four aspects: 1) fluency, 2) flexibility, 3) original, and 4) elaboration

The research data above shows that the category of students' creativity is high even though it is close to sufficient limits. However, in the implementation of learning, the teacher (lecturer) continues to motivate through project consultation. At least, it will make the students to explore ideas from teacher's (lecturer) suggestions. According to Listiani (2014: 264-276), the creativity and motivation can influence learning outcomes.

Education have to lead to the development of student creativity. It will be able to meet the evolving needs (Saparahayuningsih, 2010: 5-6). The creativity can actually is grown by appropriate learning models. The learning model that is suitable for this is the project-based learning models. According to Hasanah et.al (2018: 1-8), the teacher (lecturer) must be willing to work with the BK teacher/counselor and parents. They have to communicate to create a conducive atmosphere full of creativity. This is in accordance with what was said by Juandi et al. (2017: 130-138), teacher's teaching skills and creativity have a strong correlation with student learning achievement.
Becoming a teacher is an extraordinary challenge and requires creativity. According to Griffiths (2014: 117-129), teaching is a complex activity. However, in order to realize quality teachers, all parties need support. The role of the government is to allocate a special budget for teaching training so that teachers can be given training opportunities for the use of media in the classroom (Naz et al., 2008: 35-40).

\section{CONCLUSION}

The students' creativity is a factor in making Biology learning media projects. The creativity must be supported by students and teacher. A good motivation will produce good projects. Based on the results, the conclusions in this article are as follows. 1) The Biology learning media was created by Biology Education students such as: spinning fauna in Indonesia, biosumpit cells, plantae quick responses, digestive system scrapbook, biology ladder snakes, virus question boards, female reproductive system, bio minilab, and human skin display. 2) The score of the Biology learning media project was created by students is in the good category with an average of $88.44 ; 17 \%$ (very good category) and $83 \%$ (good category). 3) The students' creativity is in the high category with an average of $2.66 ; 28 \%$ (fair category) and $72 \%$ (high category). The students' creativity that was supported by students and teachers will obtain good projects.

\section{REFERENCES}

[1] Adinugraha F. 2017. Media pembelajaran biologi berbasis ecopreneurship. Jurnal Formatif, 7 (3): 219:233.

[2] Adinugraha F. 2018. Model pembelajaran berbasis proyek pada mata kuliah media pembelajaran. Jurnal SAP, 3 (1): 1-9.

[3] Adinugraha F. 2019. Pendekatan Kearifan Lokal dan Budaya (KALBU) dalam pembelajaran Biologi di Purworejo. 20 (1): 1-17.

[4] Bourgonje P \& Rosanne Tromp. 2011. Quality Educators: An International Study of Teacher Competencies and Standards, Oxfam Novid, Educational International, (1-167). Online at https://oxfamilibrary.openrepository.com [diunduh 10 Agustus 2019 pukul 11.57 WIB].

[5] Fathorrahman F. 2017. Kompetensi pedagogic, professional, kepribadian, dan kompetensi social dosen. Jurnal Akademika, 15 (1): 1- 6. 
[6] Fitria AD, Muh. Khalifah Mustami, \& Ainul Uyuni Taufiq. 2017. Pengembangan media Figure berbasis potensi lokal pada pembelajaran materi keanekaragaman hayati di kelas X di SMA 1 Pitu Riase Kab. Sidrap. Auladuna: Jurnal Pendidikan Dasar Islam, 4 (2): 14-28.

[7] Griffiths M. 2014. Encouraging imagination and creativity in teaching profession. European Educational Research Journal, 13 (1): 117-129.

[8] Hasanah A, Asmidir Ilyas, \& Afdal Afdal. 2018. Kreativitas siswa dan upaya guru bimbingan dan konseling (konselor) dalam pengembangannya. Insight: Jurnal Bimbingan dan Konseling, 7 (1): 1-8.

[9] Hidayat, M. T., \& Sutarjo, M. (2021). Participation and Coordination between Companies and the Cirebon City Government in Poverty Alleviation through Corporate Social Responsibility Programs. International Journal of Science and Society, 3(1), 154-172. https://doi.org/10.200609/ijsoc.v3i1.280

[10] Juandi A \& Uep Tatang Sontani. 2017. Keterampilan dan kreativitas mengajar guru sebagai determinan terhadap prestasi belajar siswa. Jurnal Pendidikan Manajemen Perkantoran, 2 (2): 130-138.

[11] Kupers E, Andreas Lehmann-Wermser, Gary McPherson, \& Paul van Geert. 2019. Children's creativity: A theoretical framework and systematic review. Review of Educational Research, 89 (1): 93-124.

[12] Listiani NM. 2014. Pengaruh kreativitas dan motivasi terhadap hasil belajar mata pelajaran produktif pemasaran pada siswa kelas XI SMK
Negeri 2 Tuban. Jurnal Ekonomi Pendidikan dan Kewirausahaan, 2 (2): 264-276.

[13] Mahnun N. 2012. Media Pembelajaran (Kajian terhadap langkah-langkah pemilihan media dan implementasinya dalam pembelajaran). Jurnal Pemikiran Islam, 37 (1): 27-35.

[14] Mukti INC \& Heru Nurcahyo. 2017. Pengembangan media pembelajaran biologi berbantuan komputer untuk meningkatkan hasil belajar peserta didik. Jurnal Inovasi Pendidikan IPA, 3 (2): 137-149.

[15] Naz AA \& Rafaqat Ali Akbar. 2008. Use of media for effective instruction its importance: some consideration. Journal of Elementary Education, 18 (1-2): 35-40.

[16] Saparahayunigsih S. 2010. Peningkatan kecerdasan dan kreativitas siswa. Kreatif: Jurnal Kependidikan Dasar, 1 (1): 1-6.

[17] Surya A, Stefanus C. Relmasira, \& Agustina Tyas Asri Hardini. 2018. Penerapan model pembelajaran Project Based Learning (PjBL) untuk meningkatkan hasil belajar dan kreatifitas siswa kelas III SD Negeri Sidorejo Lor 01 Salatiga. Jurnal Pesona Dasar, 6 (1): 41-54.

[18] Susilowati I, Himawan Arif Sutanto, \& Reni Daharti. 2013. Strategi peningkatan kompetensi guru dengan pendekatan analysis hierarchy process. JEJAK (Journal of Economic and Policy), 6 (1): 80-92.

[19] Wekesa NW \& Raphael Odhiambo Ongunya. 2016. Project Based Learning on Students' Performance in the Concept of Classification of Organisms among Secondary Schools in Kenya. Journal of Education and Practice, 7 (16): 25-31. 